Jurnal Ilmu Ilmu Agribisnis: Journal of Agribusiness Science, 9(4), Agustus 2021

\title{
PENGARUH PROGRAM UPAYA KHUSUS (UPSUS) TERHADAP PRODUKTIVITAS, BIAYA POKOK PRODUKSI DAN PENDAPATAN USAHATANI PADI DI KABUPATEN PRINGSEWU
}

\author{
(The Impact of Upaya Khusus Program (Upsus) on Productivity, Production Basic Costs \\ and Income of Rice Farming in Pringsewu Regency)
}

Desti April Yanti, Agus Hudoyo, Achdiansyah Sulaiman

Jurusan Agribisnis, Fakultas Pertanian, Universitas Lampung, Jl. Prof. Dr. Soemantri Brojonegoro No.1 Bandar Lampung 35145, e-mail: agus.hudoyo@fp.unila.ac.id

\begin{abstract}
Rice is the staple food of Indonesian people. In 2014, its production was less than its need including its losses. Therefore, during 2015-2020, in order to increase the production through increasing its yield and its cropping intensity, the Ministry of Agriculture had been implementing the program of Upaya Khusus, called Upsus. The Upsus could be success if the farmers who participated in this program spent less the rice standard cost and obtained bigger profit. The question was whether the Upsus could increase yield, decrease standard cost and increase profit. Accordingly, the objective of this study was to answer this question. There were 30 respondents chosen by the simple random sampling method from six villages of three subdistricts. Each respondent was interviewed his farming budget in four seasons, i.e. rainy season 2014/2015, dry season 2015, rainy season 2017/2018, and dry season 2018. Consequently, the number of observation was 120. The data farming budget were used for getting the three following variables, i.e. yield (ton/ha), production standard cost ( $\mathrm{Rp} / \mathrm{kg})$, and profit (Rp million/ha). The data were analyzed by using three multiple regression models. This study revealed that the Upsus was statistically significant on increasing its yield, decreasing its standard cost and increasing its profit. By implementing the Upsus, the increment in yield and profit of rice farming were 3 percent and 30 percent, respectively. The decrease in standard cost was 6 percent. The average yield, the standard cost and the profit of rice farming in Upsus were as follows 5,20 ton/ha, Rp4.154,-/kg and Rp6,82 million/ha
\end{abstract}

Keywords: profit, standard cost, upsus, yield

Received:16 February 2020 Revised:23 June 2020 Accepted:6 July 2020 DOI: http://dx.doi.org/10.23960/jiia.v9i4.5396

\section{PENDAHULUAN}

Beras merupakan makanan pokok masyarakat Indonesia. Menurut data FAO (2020), kebutuhan dan kehilangan padi karena tercecer di Indonesia pada 2014 mencapai 71,71 juta ton, sedangkan total produksinya sebanyak 70,85 juta ton. Hal ini menunjukkan bahwa produksi padi masih kurang 0,86 juta ton, agar mampu mencukupi kebutuhan masyarakat oleh sebab itu, pada 2015 Kementerian Pertanian pada Kabinet Kerja (2014-2019) mencanangkan Program Upaya Khusus (Upsus) padi, jagung dan kedelai (Pajale). Tujuannya untuk meningkatkan produksi padi dengan cara meningkatkan produktivitas dan intensitas tanam.

Upaya untuk meningkatkan produktivitas tanaman pangan melalui Program Upsus Pajale tertuang dalam peraturan Menteri Pertanian RI No. 03/Permentan/OT.140/2/2015. Program Upsus merupakan usaha bersama yang dilakukan secara khusus untuk mewujudkan target yang telah ditetapkan melalui kerjasama dengan berbagai pihak, seperti petani, penyuluh, Babinsa, mahasiswa, serta pihak-pihak lain yang terlibat dan mendukung dalam mencapai target meningkatkan produksi dan produktivitas tanaman pangan.

Menurut Permentan No. 03/2015, dalam menunjang tercapainya target produksi yang telah ditetapkan untuk mencapai swasembada pangan, dilakukan kegiatan Program Upsus yang terdiri dari: Pengembangan jaringan irigasi,optimalisasi lahan, pengembangan System of Rice Intensification (SRI), Gerakan Penerapan Pengolahan Tanaman Terpadu (GP-PTT) padi, penyedian bantuan benih, penyediaan bantuan pupuk, penyediaan bantuan alat dan mesin pertanian (Alsintan), pengendalian OPT dan dampak perubahan iklim, asuransi pertanian serta pengawalan dan pendampingan. 
Upsus dapat dikatakan berhasil jika petani yang berpartisipasi dalam program Upsus dapat meningkatkan produktivitas, menurunkan biaya pokok produksi dan meningkatkan pendapatan usahatani padi. Berdasarkan hal tersebut, pertanyaannya adalah apakah Upsus dapat meningkatkan produktivitas, menurunkan biaya pokok produksi, dan meningkatkan pendapatan usahatani padi. Oleh karena itu, penelitian ini bertujuan untuk menjawab pertanyaan tersebut.

\section{METODE PENELITIAN}

Penelitian ini menggunakan metode survei. Sampel yang digunakan adalah petani padi di Kabupaten Pringsewu. Metode pengambilan sampel dilakukan dengan menggunakan metode acak sederhana (simple random sampling ).Penelitian ini menggunakan 30 responden dengan 120 observasi sehingga total sampel yang digunakan adalah 120 observasi (sampel) yang merupakan petani padi di Kabupaten Pringsewu. Menurut Cohen (2007), semakin besar sampel yang diambil dalam suatu populasi maka hasil yang diperoleh akan semakin baik, namun sampel yang akan digunakan memiliki batas minimal yang diambil yaitu sebesar 30 sampel. Responden yang digunakan dalam penelitian ini berjumlah 30 petani yang berasal dari enam desa di tiga kecamatan yaitu Kecamatan Ambarawa, Kecamatan Gadingrejo, dan Kecamatan Adiluwih di Kabupaten Pringsewu. Setiap responden diambil empat data usahatani yaitu MH 2014/2015 dan MK 2015 untuk non-upsus serta MH 2017/2018 dan MK 2018 pada saat upsus. Jadi total observasi berjumlah 120. Hasil observasi penelitian dapat dilihat pada Tabel 1. Metode pengumpulan data yang digunakan adalah observasi, wawancara dan mengingat kembali (recall).Pengambilan data dalam penelitian dilaksanakan pada bulan Agustus 2019.

Data dianalisis dengan menggunakan model regresi berganda. Variabel terikat yang digunakan adalah produktivitas, biaya pokok produksi dan pendapatan. Batasan variabel terikat adalah sebagai berikut: Produktivitas adalah produksi padi dalam satu hektar pada satu musim tanam (ton/ha). Biaya pokok produksi adalah seluruh biaya per kilogram untuk usahatani padi dalam satu musim tanam (Rp/kg). Pendapatan (keuntungan) adalah penerimaan dikurang total biaya usahatani padi setiap satu hektar pada satu musim tanam (Rp juta/ha). Harga input yang digunakan besarnya sama yaitu harga input pada saat Upsus
(2017/2018). Model matematis pada penelitian ini adalah sebagai berikut:

$Y_{1 i}=\hat{a}_{0}+\hat{a}_{1} D_{1 i}+\hat{a}_{2} D_{2 i}+\hat{a}_{3} D_{3 i}+e_{1 i}$
$Y_{2 i}=\hat{b}_{0}+\hat{b}_{1} D_{1 i}+\hat{b}_{2} D_{2 i}+\hat{b}_{3} D_{3 i}+e_{2 i}$
$Y_{3 i}=\hat{c}_{0}+\hat{c}_{1} D_{1 i}+\hat{c}_{2} D_{2 i}+\hat{c}_{3} D_{3 i}+e_{3 i}$

Keterangan:

$\mathrm{Y}_{1} \quad=$ Produktivitas (ton/ha)

$\mathrm{Y}_{2}=$ Biaya pokok produksi $(\mathrm{Rp} / \mathrm{kg})$

$\mathrm{Y}_{3} \quad=$ Pendapatan (Rp juta/ha)

$\hat{a}, \hat{b}, \hat{c}, \quad=$ Koefisien Penduga

$\hat{a}_{0}, \hat{b}_{0}, \hat{c}_{0}=$ Intersep

$\mathrm{i} \quad=$ Observasi $1,2,3, \ldots, 120$

$\mathrm{D}_{1} \quad=$ Program Upsus $\mathrm{D}_{1}=1 ;$ Upsus, $\mathrm{D}_{1}=0$; Non-upsus

$\mathrm{D}_{2} \quad=$ Musim Tanam (MT) $\mathrm{D}_{2}=1 ; \mathrm{MT} 1, \mathrm{D}_{2}=0 ; \mathrm{MT} 2$

$\mathrm{D}_{3} \quad=$ Lokasi $\mathrm{D}_{3}: 1$ Lokasi 1, $\mathrm{D}_{3}=0$; Lokasi 2

$\mathrm{e}_{1}, \mathrm{e}_{2}, \mathrm{e}_{3}=$ Galat

\section{HASIL DAN PEMBAHASAN}

Kabupaten Pringsewu mempunyai luas wilayah $625 \mathrm{~km}^{2}$. Potensi sumber daya alam yang dimiliki Kabupaten Pringsewu sebagian besar dimanfaatkan untuk kegiatan pertanian.Struktur perekonomian Kabupaten Pringsewu pada tahun 2017 masih didominasi oleh kategori pertanian, kehutanan, dan perikanan dengan kontribusi sebesar 25,85 persen. Menurut Badan Pusat Statistika (2018) luas panen padi di Kabupaten Pringsewu mencapai 25.497 ha dengan total produksi sebesar 138.009 ton. Kabupaten Pringsewu merupakan salah satu kabupaten penghasil beras di Provinsi Lampung karena memiliki 19 Daerah Aliran Sungai (DAS) yang menunjang petani dalam memenuhi kebutuhan air untuk melakukan usahatani padi. DAS yang terluas yaitu Way Sekampung, Way Mangga dan Way Tebu.

Tabel 1. Jumlah observasi penelitian

\begin{tabular}{clccc}
\hline Observasi & Lokasi & Upsus & Non-upsus & Jumlah \\
\hline \multirow{3}{*}{ MH } & Lokasi 1 & 20 & 20 & 40 \\
& Lokasi 2 & 10 & 10 & 20 \\
\cline { 2 - 5 } & Jumlah & 30 & 30 & 60 \\
\hline \multirow{3}{*}{ MK } & Lokasi 1 & 20 & 20 & 40 \\
& Lokasi 2 & 10 & 10 & 20 \\
\cline { 2 - 5 } & Jumlah & 30 & 30 & 60 \\
\hline Jumlah & & 60 & 60 & 120 \\
\hline
\end{tabular}


Petani padi di Kabupaten Pringsewu memiliki ratarata pendidikan sembilan tahun atau setara dengan SMP. Rata-rata umur petani 51 tahun yang berarti termasuk usia produktif. Sehingga petani masih mempunyai kemampuan untuk bekerja dan berfikir lebih keras. Menurut Mantra (2003), manusia berada pada usia produktif pada usia 15-64 tahun.

Petani melakukan usahatani padi dan usaha lainnya untuk mencukupi kebutuhan keluarganya. Ratarata pendapatan petani yaitu $\mathrm{Rp} 23,85$ juta/tahun atau Rp1,99 juta/bulan. Upah minimum Kabupaten Pringsewu yaitu Rp1,91 juta/bulan. Usahatani padi memberikan kontribusi terbesar terhadap pendapatan rumah tangga petani yaitu sebesar 52,08 persen. Hasil penelitian yang dilakukan di Kabupaten Pringsewu dari 120 data usahatani padi diperoleh rata-rata produktivitas padi yaitu 5,23 ton/ha. Rata-rata biaya pokok produksi usahatani padi yaitu $\mathrm{Rp} 4.226$, $-/ \mathrm{kg}$, serta rata-rata pendapatan usahatani padi yang diperoleh Rp6,24 juta/ha.

\section{Gambaran Usahatani dan Pelaksanaan Upsus Padi}

Proses budidaya padi pada saat Upsus tidak banyak mengalami perubahan. Hal ini dilatar belakangi oleh pengalaman petani dalam melakukan usahatani yang sudah puluhan tahun. Petani menganggap bahwa teknik budidaya padi yang dikenalkan dalam Upsus tidak jauh berbeda dengan teknik budidaya yang selama ini petani terapkan. Sistem jajar legowo mulai banyak diterapkan oleh petani pada saat Upsus. Sistem jajar legowo dianjurkan oleh pendamping karena berpotensi dapat meningkatkan produksi. Cara tanam ini tidak memerlukan banyak benih karena jarak tanam yang lebih lebar dibandingkan dengan sistem tegal. Sistem jajar legowo yang banyak diterapkan oleh petani yaitu jajar legowo 2:1, 4:1, 5:1, 6:1, 7:1, dan 10:1.

Varietas benih padi yang banyak digunakan oleh petani yaitu Ciherang, Mikongga, dan Mapan. Varietas Ciherang masih menjadi andalan petani dalam melakukan usahatani padi. Petani sering memperoleh bantuan benih padi pada saat Upsus. Namun, petani banyak yang menolak untuk menanam benih bantuan yang diberikan kepada petani. Hal ini terjadi karena petani menganggap bahwa benih bantuan yang diberikan memiliki kualitas yang rendah. Petani lebih memilih untuk membeli benih sendiri.
Pengadaan pupuk subsidi oleh petani pada Upsus dibantu oleh Dinas Pertanian Kebupaten dan penyuluh dengan menebusnya melalui bank yang bekerjasama langsung dengan distributor. Pada saat non-upsus petani memperoleh pupuk yang diorganisir oleh kelompok tani yang bekerjasama dengan pedagang pengecer. Kelebihan adanya Program Upsus petani lebih pasti untuk memperoleh pupuk, jumlah dan waktu ketersedianya lebih terjamin. Pembayaran pupuk oleh petani dilakukan dengan metode pembayaran pada saat panen (yarnen) dengan menggunakan gabah. Jumlah gabah disesuaikan dengan kesepakatan kelompok tani masing-masing. Pengadaan ALSINTAN didampingi oleh penyuluh yang disalurkan kepada kelompok tani. Bantuan alsintan yang telah digunakan secara masal seperti: Hand Traktor, Hand Sprayer, Perontok Padi dan Pompa Air, kecuali Combaineharvester masih dalam tahap percobaan dan pembelajaran.

Pengawalan dan pendampingan pada saat Upsus banyak dilakukan mulai dari penyuluhan kepada petani, pendampingan dalam pengendalian hama dan penyakit tanaman serta pendampingan dalam bantuan pengadaan pupuk dan bantuan pengadaan ALSINTAN. Penyuluhan kepada petani untuk menyampaikan informasi mengenai teknologi baru dalam melakukan budidaya padi untuk meningkatkan produksi padi baik teknologi dalam proses budidaya ataupun teknologi yang berkaitan dengan alat dan mesin pertanian yang dapat memberikan pengetahuan baru bagi petani.

\section{Pengaruh Upsus terhadap Produktivitas}

Hasil analisis bahwa pengaruh Upsus terhadap produktivitas dapat dilihat pada Tabel 2. Tabel ini menunjukkan bahwa nilai $R^{2}$ sebesar 62,32 persen, artinya 62,32 persen produktivitas padi dapat dijelaskan oleh variabel Upsus, MT, dan lokasi, sedangkan sisanya sebesar 37,68 persen dijelaskan oleh variabel lain yang tidak dimasukkan ke dalam model. F-hitung pada hasil regresi produktivitas padi memiliki taraf nyata $\alpha$ sebesar 1 persen. Hal ini berarti secara bersama-sama variabel Upsus, MT, dan lokasi berpengaruh nyata terhadap produktivitas padi di Kabupaten Pringsewu.

Berdasarkan uji t menunjukkan bahwa variabel Upsus, musim tanam, dan lokasi signifikan terhadap produktivitas padi, artinya semua variabel yang digunakan berpengaruh nyata terhadap produktivitas padi. Upsus berpengaruh nyata 
terhadap produkivitas padi dengan taraf nyata $\alpha$ sebesar 10,00 persen, sehingga dengan adanya Program Upsus Pajale produktivitas padi di Kabupaten Pringsewu secara rata-rata lebih tinggi sebesar 0,17 ton/ha daripada produktivitas Nonupsus dengan mengontrol variabel musim tanam dan variabel lokasi. Model persamaan yang diperoleh berdasarkan pada Tabel 2 adalah sebagai berikut:

$$
\bar{Y}_{1}=4,08+0,17 \mathrm{D}_{1}+1,24 \mathrm{D}_{2}+0,66 \mathrm{D}_{3}
$$

Variabel bebas yang digunakan kemudian dimasukkan ke dalam model persamaan yang telah diperoleh. Maka diperoleh rata-rata produktivitas padi pada saat upsus adalah 5,20 ton/ha, sedangkan rata-rata produktivitas padi Non-upsus adalah 5,03 ton/ha. Rata-rata produktivitas padi pada saat Upsus lebih besar daripada rata-rata produktivitas padi Non-upsus. Hal ini menunjukkan bahwa Program Upsus berpengaruh positif terhadap peningkatan produktivitas padi di Kabupaten Pringsewu. Penelitian ini sejalan dengan penelitian Wijaya, Widyantara, dan Dewi (2016) yang menyatakan produktivitas rata-rata padi setelah adanya bantuan Program Upsus Pajale mengalami peningkatan yang menunjukkan bahwa pelaksaan Program Upsus terlaksana efektif sehingga dapat memenuhi kebutuhan petani dan diharapkan dapat membantu peningkatan taraf hidup petani. Pada penelitian ini peningkatan produktivitas rata-rata setelah adanya bantuan Program Upsus adalah sebesar 0,93 ton/ha. Selisih peningkatan produktivitas padi adalah sebesar 0,17 ton/ha/tahun. Hal ini sejalan dengan penelitian Hudoyo dan Nurmayasari (2018) yang menyatakan bahwa rata-rata peningkatan produktivitas padi pada saat Program Upsus mengalami peningkatan, namun pada penelitian ini peningkatan produktivitas padi adalah sebesar 0,23 ton/ha/tahun. Peningkatan prodiktivitas padi pada saat Upsus adalah 3,00 persen. Peningkatan produktivitas padi dirasa masih kecil oleh petani,

Tabel 2. Pengaruh Upsus terhadap produktivitas padi (ton/ha) tahun 2018

\begin{tabular}{llr}
\hline \multicolumn{1}{c}{ Variabel Bebas } & Koefisien & t Stat \\
\hline Intercept & $4,08 * * *$ & 36,10 \\
Upsus (D1) & $0,17 *$ & 1,73 \\
Musim Tanam (D2) & $1,24 * * *$ & 12,30 \\
Lokasi(D3) & $0,66 * * *$ & 6,12 \\
\hline F- hitung & $63,96 * * *$ & \\
$\mathrm{R}^{2}(\%)$ & 62,32 & \\
\hline Keterangan: $*, * *$, dan $* * *$ adalah signifikan, secara berturut-turut
\end{tabular}

Keterangan: *,**, dan $* * *$ adalah signifikan, secara berturut-turut dengan taraf nyata $(\alpha) 10 \%, 5 \%$ dan $1 \%$. namun jika dilihat secara nasional peningkatan produktivitas padi sebesar 3,00 persen sudah cukup besar. Peningkatan produktivitas padi di Kabupaten Pringsewu menunjukkan bahwa pelaksanaan Program Upsus berdampak positif bagi produktivitas usahatani padi.

Hal ini sejalan dengan penelitian Saputra, Antara, dan Effendy (2018) yang menyatakan pelaksaan Program Upsus terhadap komoditas padi di Desa Jono OgeKecamatan Sigi Biromaru telah memberikan dampak positifterhadap pertumbuhan produktivitas tanaman padi dengan produktivitas padi sebelum dan sesudah Program Upsus mempunyai taraf korelasi 76,30 persen berarti produktivitas padi meningkat dengan adanya Program Upsus Pajale. Pemerintah dianggap telah berhasil karena produktivitas yang meningkat ada hubungannya dengan Program Upsus Pajale.

Peningkatan produksi dan produktivitas yang terjadi di Kabupaten Pringsewu tidak lepas dari peran serta pendamping atau penyuluh dalam pelakukan pendampingan kepada petani dalam melakukan kegiatan usahatani. Pendampingan yang dilakukan dalam Program Upsus padi memberikan banyak pengetahuan baru bagi petani mengenai teknologi-teknologi dalam melakukan usahatani terutama teknologi dalam melakukan budidaya yang dapat meningkatkan produksi dan pendapatan.

Penyuluh memberikan informasi dan wawasan baru bagi petani mengenai teknik cara tanam jajar legowo dan hasil produksi yang lebih tinggi. Hal tersebut membuat petani banyak yang menerapkan sistem jajar legowo dalam proses budidaya yang dilakukan dan terbukti bahwa cara tanam menggunakan teknik jajar lewogo yang mulai banyak diterapkan oleh petani pada saat Upsus memberikan dampak positif terhadap peningkatan produksi yang diterima oleh petani dibandingkan dengan sistem tegal. Hal ini sejalan dengan penelitian Darwis (2017) yang mengatakan bahwa produktivitas petani di Kecamatan Ternate Rianttang Kabupaten Bone dengan sistem jajar legowo lebih tinggi nilainya dibandingkan dengan petani yang menggunakan sistem non jajar legowo (tegal).

Selain itu, penerapan teknologi mengenai teknik tanam jajar legowo ini juga sejalan dengan penelitian Nugroho et al. (2018) yang mengatakan bahwa pengujian menggunakan teknologi tanam jajar legowo dan berdasarkan budidaya yang sesuai dengan kebiasan yang diterapkan oleh petani 
memberikan hasil yang berbeda. Rata-rata hasil panen yang diperoleh yaitu 5,50 ton/ha lebih tinggi dibandingkan dengan hasil panen berdasarkan budidaya sesuai dengan kebiasaan petani yaitu 4,50 ton/ha yang dilakukan di Kabupaten Kendal Jawa Tengah.

Peningkatan produktivitas padi dengan adanya Program Upsus padi tidak terlalu besar yaitu hanya 3,00 persen dibandingkan produktivitas pada saat non-upsus hal ini bisa saja terjadi karena waktu pelaksanaan program yang sangat singkat yaitu sekitar lima tahun yang membuat pelaksanaanya belum maksimal di tingkat petani. Hal ini sejalan dengan penelitian Nugroho et al. (2017) yang menyatakan bahwa masalah utama dalam pendampingan Upsus di kota kendal yakni waktu pendampingan yang telalu pendek sehingga belum mampu sepenuhnya mengatasi permasalahan petani.

\section{Pengaruh Upsus terhadap Biaya Pokok}

Hasil analisis bahwa Pengaruh upsus terhadap biaya pokok dapat dilihat pada Tabel 3. Tabel ini menunjukkan nilai $R^{2}$ yang di peroleh dari hasil regresi yang peroleh sebesar 57,35 persen yang artinya 57,35 persen biaya pokok padi dapat dijelaskan oleh oleh variabel Upsus, MT, dan lokasi, sedangkan sisanya sebesar 42,65 persen dijelaskan oleh variabel lain yang tidak dimasukan ke dalam model. F-hitung pada hasil resgresi biaya pokok padi memiliki taraf nyata $\alpha$ adalalah 1,00 persen. Artinya secara bersama-sama variabel Upsus, MT, dan lokasi berpengaruh nyata terhadap biaya pokok padi di Kabupaten Pringsewu.

Hasil uji t yang telah dilakukan diperoleh variabel bebas signifikan terhadap biaya pokok padi, artinya variabel bebas yang digunakan berpengaruh nyata terhadap penurunan biaya pokok padi. Upsus berpengaruh nyata terhadap biaya pokok padi dengan taraf nyata $\alpha$ sebesar 5,00 persen. Hasil regresi menunjukkan bahwa dengan adanya Program Upsus Pajale dapat menurunkan rata-rata biaya pokok usahatani padi sebesar $\mathrm{Rp} 247,-/ \mathrm{kg}$ yang harus dikeluarkan oleh petani di bandingkan dengan biaya pokok Non-upsus. Variabel musim tanam dan variabel lokasi digunakan sebagai variabel kontrol, dimasukkan ke dalam persamaan model yang telah diperoleh.Ratarata biaya pokok padi di Kabupaten Pringsewudengan adanya Program Upsus adalah Rp4.154,-/kg, sedangkan rata-rata biaya pokok padi Non-upsus adalah Rp4.402,-/kg.
Tabel 3. Pengaruh Upsus terhadap biaya pokok padi $(\mathrm{Rp} / \mathrm{Kg})$ tahun 2019

\begin{tabular}{lcr}
\hline \multicolumn{1}{c}{ Variabel Bebas } & Koefisien & t Stat \\
\hline Intercept & $5.204 * * *$ & 43,00 \\
Upsus (D1) & $-248 * *$ & $-2,29$ \\
Musim Tanam (D2) & $-1.297 * * *$ & $-11,98$ \\
Lokasi (D3) & $-308 * * *$ & $-2,68$ \\
\hline F- hitung & $52,00 * * *$ \\
$\mathrm{R}^{2}(\%)$ & 57,35 & \\
\hline Keterangan: $*, * *$, dan $* * *$ adalah signifikan, secara berturut-turut \\
dengan taraf nyata $(\alpha) 10 \%, 5 \%$ dan $1 \%$.
\end{tabular}

Hal ini menunjukkan bahwa terjadi penurunan biaya pokok usahatani padi Upsus. Presentase penurunan biaya pokok usahatani padi di Kabupaten Pringsewu adalah 6,00 persen. Model persamaan biaya pokok padi berdasarkan pada Tabel 3 adalah sebagai berikut:

$\overline{\mathrm{Y}}_{2}=5.204-248 \mathrm{D}_{1}-1.297 \mathrm{D}_{2}-308 \mathrm{D}_{3}$

Harga rata-rata penjualan padi (gkg) di Kabupaten Pringsewu adalah sebesar Rp5.364,-/kg. Secara umum harga jual padi oleh petani lebih besar dari rata-rata biaya pokok, baik Upsus dan Non-upsus. Ini menunjukkan bahwa petani sudah memperoleh keuntungan dari usahatani padi yang dilakukannya, sehingga sampai saat ini masih banyak petani yang masih melakukan usahatani padi sebagai sumber pendapatan. Hal ini sejalan dengan penelitian Saputra, Hoaryono, dan Santoso (2014) yang mengatakan bahwa usatani padi di Kecamatan Gedong Tataan Kabupaten Pesawaran menguntungkan untuk diusahakan dengan nilai $\mathrm{R} / \mathrm{C}$ ratio pada usahatani padi yaitu sebesar 1,81 .

\section{Pengaruh Upsus terhadap Pendapatan}

Hasil analisis bahwa pengaruh upsus terhadap pendapatan dapat dilihat pada Tabel 4. Tabel ini menunjukkan bahwa nilai $R^{2}$ sebesar 41,80, yang artinya 41,80 persen pendapatan padi dapat dijelaskan oleh variabel Upsus, MT, dan lokasi, sedangkan sisanya sebesar 58,20 persen dijelaskan oleh variabel lain yang tidak dimasukan ke dalam model. F-hitung pada hasil regresi pendapatan padi memiliki taraf nyata $\alpha$ sebesar 1,00 persen. Artinya secara bersama-sama variabel Upsus, MT, dan lokasi berpengaruh nyata terhadap pendapatan padi di Kabupaten Pringsewu.

Hasil uji t menunjukkan bahwa variabel bebas yang digunakan signifikan terhadap pendapatan padi, ini artinya bahwa variabel bebas yang digunakan berpengaruh nyata terhadap pendapatan 
padi. Upsus perpengaruh nyata terhadap pendapatan petani padi dengan taraf nyata $\alpha$ sebesar 1,00 persen. Artinya, dengan mengontrol variabel musim tanam dan lokasi pendapatan petani padi dengan adanya Program Upsus ratarata selisihnya lebih tinggi sebesar Rp1,57 juta/ha,daripada pendapatan petani padi Nonupsus.

Model persamaan yang diperoleh berdasarkan pada Tabel 4 adalah sebagai berikut:

$\overline{\mathrm{Y}}_{3}=2,26+1,57 \mathrm{D}_{1}+4,77 \mathrm{D}_{2}+1,22 \mathrm{D}_{3}$.

Variabel bebas yang digunakan kemudian dimasukkan ke dalam model persamaanyang telah diperoleh. Rata-rata pendapatan petani padi Upsus lebih tinggi dibandingkan dengan pendapatan petani non-upsus. Rata-rata pendapatan petani padi pada saat upsus adalah sebesar Rp6,82 juta/ha. Rata-rata pendapatan petani padi nonupsus adalah sebesar Rp5,25 juta/ha. Hasil ini menunjukkan bahwa adanya peningkatan pendapatan yang diterima oleh petani Upsus. Selisih rata-rata peningkatan pendapatan usahatani padi pada saat Upsus yaitu sebesar Rp1,57 juta/ha hal ini sejalan denga Pratama (2016) yang menyatakan bahwa Program Upsus berdampak positif terhadap pendapatan petani, pada penelitian ini selisih peningkatan pendapatan petani adalah sebesar Rp2.67 juta/ha. Presentase peningkatan pendapatan yang diterima petani ada adalah sebesar 30,00 persen.

Menurut hasil penelitian Murdani, Wijaya, dan Rosanti(2015), pendapatan atas biaya total usahatani padi di Kabupaten Pringsewu rata-rata pada MT 1 yaitu sebesar Rp6,27 juta dan MT 2 yaitu Rp5,01 juta. Pada penelitian Nurjayanti, Effendi, dan Nurmayasari (2016), rata-rata pendapatan atas biaya total petani padi anorganik di Kabupaten Pringsewu MT 1 dan MT 2 yaitu Rp10,47 juta/ha dan Rp13,99 juta/ha.

\section{KESIMPULAN}

Program Upsus berpengaruh nyata terhadap peningkatan produktivitas $\quad(\alpha=10 \%)$, penurunanbiaya pokok produksi $(\alpha=5 \%)$, dan peningkatan pendapatan $(\alpha=1 \%)$ usahatani padi. Pada Upsus, produktivitas dan pendapatan usahatani padi secara berturut-turut meningkat sebesar 3,00 persen dan 30,00 persen. Selain itu, biaya pokok produksi menurun sebesar 6,00 persen. Rata-rata produktivitas, biaya pokok dan
Tabel 4. Pengaruh Upsus terhadap pendapatan usahatani padi (Juta Rp/ha) tahun 2019

\begin{tabular}{lcc}
\hline Variabel Bebas & Koefisien & t Stat \\
\hline Intercept & $2,26 * * *$ & 3,57 \\
Upsus (D1) & $1,57^{* * *}$ & 2,78 \\
Musim Tanam(D2) & $4,77^{* * *}$ & 8,45 \\
Lokasi (D3) & $1,22^{* *}$ & 2,03 \\
\hline F-hitung & $27,77^{* * *}$ \\
$\mathrm{R}^{2}(\%)$ & 41,80 & \\
\hline Keterangan: *,**, dan $* * *$ adalah signifikan, secara berturut-turut \\
dengan taraf nyata $(\alpha) 10 \%, 5 \%$ dan $1 \%$.
\end{tabular}

pendapatan usahatani padi pada saat Upsus secara berturut-turut adalah 5,20 ton/ha, Rp4.154,-/kg dan Rp6,82 juta/ha.

\section{DAFTAR PUSTAKA}

BPS [Badan Pusat Statistika]. 2018. Pringsewu Dalam Angka 2018. Badan Pusat Statistika. Provinsi Lampung.

Cohen L, Moarion L, dan Marrioson K. 2007. Research Methods In Education F. Sixth Edition. New York. Routledge.

Darwis K. 2017. Kontribusi penerapan sistem tanam legowo terhadap pendapatan dan kelayakan usahatani padi di Kecamatan Ternate Riattang Kabupaten Bone. Jurnal $\begin{array}{llll}\text { Galung Tropika, } 6 & \text { (2):185-192. }\end{array}$ https://jurnalpertanianumpar.com/index.php/jg t/article/view/239. [10 Agustus 2019].

FAO [Food and Agriculture Organization]. 2020. FAOSTAT.

http://www.fao.org/faostat/en/\#data. Agustus 2019].

Hudoyo A dan Nurmayasari I. 2018. Pengaruh Program Intensifikasi Terhadap Peningkatan Produktivitas Padi Di Indonesia. Prosiding Seminar dan Lokakarya FKPTPI. http://repository.lppm.unila.ac.id/9864/. [13 Agustus 2019].

Kementerian Pertanian. 2015. Peraturan Menteri Pertanian RI No. O3/Permentan/Ot. 140/2/2015 Tentang Pedoman Upsus Peningkatan Produksi Padi, Jagung Dan Kedelai Melalui Program Perbaikan Jaringan Irigasi dan Sarana Pendukungnya Tahun 2015. Jakarta.

Mantra IBM. 2013. Demografi Umum. Pustaka Pelajar. Jogjakarta.

Nugroho AD, Charisma UF, Ria PA, Lendy VI, Ceria L, Setiya TP, Novi A, Andri A, Ely WB, danDika AP. 2018. Pelaksanaan program upaya khusus (Upsus) swasembada pangan berkelanjutan di Kabupaten Kendal Provinsi Jawa Tengah. Jurnal Pengabdian Dan 
Pemberdayaan Masyarakat, 2 (2): 287-296. http://jurnalnasional.ump.ac.id/index.php/JPP M/article/view/2519. [12 Agustus 2019].

Nurjayanti A, Effendi I, dan Nurmayasari I. 2016. Pendapatan dan manfaat usahatani padi organik di Kabupaten Pringsewu. Jurnal Ilmu $\begin{array}{lll}\text { Ilmu Agribisnis, } 4 & \text { (2):126-133. }\end{array}$ https://jurnal.fp.unila.ac.id/index.php/JIA/artic le/view/1229. [12 Agustus 2019].

Mardani MI, Wijaya S, dan Rosanti N. 2015. Pendapatan dan tingkat kesejahteraan rumah tangga petani padi (oryza sativa) di Kecamatan Gadingrejo Kabupaten Pringsewu. Jurnal Ilmu Ilmu Agribisnis, 3 (2): 167-172. https://jurnal.fp.unila.ac.id/index.php/JIA/artic le/view/1035. [12 Agustus 2019].

Pratama APR. 2016. Dampak Program Upsus Padi Terhadap Produksi dan Pendapatan Petani Di Kecamatan Aikmel Kabupaten Lombok Timur. Skripsi. Universitas Mataram.

Saputra MD, Antara M, dan Effendy. 2018. Dampak program pajale terhadap produktivitas padi sawah di Desa Jono Oge Kecamatan Sigi Biromaru Kabupaten Sigi. Jurnal Agroland, 25 (2): 96-105. http://jurnal.untad.ac.id/jurnal/index.php/AGR OLAND/article/view/10881. [13 Agustus 2019].

Saputra RD, Haryono D, dan Santoso H. 2014. Produksi dan pendapatan usahatani padi sawah hibrida dan inhibrida di Kecamatan Tataan Kabupaten Pesawaran. Jurnal Ilmu Ilmu Agribisnis, 2 (3): 196-205. https://jurnal.fp.unila.ac.id/index.php/JIA/artic le/view/801. [11 Agustus 2019].

Wijaya IGMAS, Widyantara IW dan Dewi IAL. 2016. Efektivitas alokasi input usahatani padi dalam program Upsus Pajale di Subak Gadungan Delod Desa, Desa Gadungan, Kabupaten Tabanan. E-Jurnal Agribisnis dan $\begin{array}{lll}\text { Agrowisata, } & 5 & \text { (3): }\end{array}$ https://ojs.unud.ac.id/index.php/JAA/article/vi ew/22763. [12 Agustus 2019]. 